\title{
Pengaruh Implementasi Good Corporate Governance dan Strategi Bisnis terhadap Kinerja Perusahaan: Studi Kasus BUMN di Indonesia Tahun 2013-2018
}

\author{
Ichwan Lazuardi Natapermana \\ Winwin Yadiati \\ Euis Nurhayati \\ Akuntansi, Universitas Padjajaran, Indonesia \\ Korespondensi penulis: ichwanlazuardi.n@gmail.com
}

\begin{abstract}
State-Owned Enterprise (SOE) is one of the agents of economic activity in the national economy of Indonesia that has an important role in managing the national economy to realize the welfare of society. At present, SOEs have often received critical attention from the public because they are seen as inefficient, wasteful of resources utilization, laden with corruption, and have lower level profitability. The implementtation of Good Corporate Governance (GCG) and the right of business strategy is expected to improve the performance of SOEs both financially and non-financially. The purpose of this study was to determine the effect of GCG implementation and business strategy on firm performance. In this study, financial performance was measured using Return on Equity (ROE) and non-financial performance used Customer Satisfaction Index (CSI). The method used in this research was a partial regression of panel data through the determined of the estimation model after the classical assumption test. The sample used in this study was 22 SOEs (BUMN) that met the sample criteria. The results showed that there was a significant effect of the implementation of GCG on ROE and CSI. But, there was not a significant effect of the implementation of its' business strategies on ROE, otherwise the significant effect on CSI.
\end{abstract}

Keywords: Business strategy; Customer Satisfaction Index; Firm performance; Good Corporate Governance; Return on Equity.

\begin{abstract}
Abstrak. Badan Usaha Milik Negara (BUMN) merupakan salah satu pelaku kegiatan ekonomi dalam perekonomian nasional yang memiliki peranan penting dalam penyelenggaraan perekonomian nasional guna mewujudkan kesejahteraan masyarakat. BUMN selama ini sering mendapat sorotan kritis dari masyarakat karena dipandang tidak efisien, boros pemanfaatan sumber daya, sarat korupsi, dan memiliki profitabilitas yang rendah. Implementasi Good Corporate Governance (GCG) serta strategi bisnis yang tepat diharapkan dapat meningkatkan kinerja BUMN baik secara finansial maupun non finansial. Tujuan penelitian ini adalah untuk mengetahui pengaruh implementasi GCG dan strategi bisnis terhadap kinerja perusahaan. Pada penelitian ini, kinerja keuangan diukur menggunakan Return on Equity (ROE) dan non-keuangan dengan Cus-
\end{abstract}


tomer Satisfaction Index (CSI). Metode penelitian yang digunakan adalah regresi parsial pada data panel melalui penilaian model estimasi setelah dilakukan uji asumsi klasik. Sampel yang digunakan pada penelitian ini adalah 22 BUMN yang memenuhi kriteria penentuan sampel. Hasil penelitian menunjukkan bahwa ada pengaruh signifikan implementasi GCG terhadap ROE dan CSI. Hasil penelitian juga menemukan adanya pengaruh tidak signifikan implementasi strategi bisnis terhadap ROE, tetapi signifikan terhadap CSI.

Kata Kunci: Customer Satisfaction Index; Good Corporate Governance; Kinerja perusahaan; Return on Equity; Strategi Bisnis.

Article Info:

Received: November 20, $2019 \quad$ Accepted: January 29, $2020 \quad$ Available Online: March 11, 2020

DOI: http://dx.doi.org/10.30588/jmp.v9i2.579

\section{LATAR BELAKANG}

Undang-Undang Dasar (UUD) 1945 mengamanatkan bahwa aktor utama yang berperan dalam sistem perekonomian di Indonesia adalah sektor pemerintah, koperasi, masyarakat atau individu, dan sektor swasta baik dalam maupun luar negeri. Badan Usaha Milik Negara (BUMN) merupakan salah satu pelaku kegiatan ekonomi dalam perekonomian nasional yang berdasarkan demokrasi ekonomi dan memiliki peran penting dalam penyelenggaraan perekonomian nasional guna mewujudkan kesejahteraan masyarakat berdasarkan Undang-Undang Republik Indonesia (UU RI) nomor 19 tahun 2003 tentang BUMN (Sekretariat Negara RI, 2003). Agar mampu turut andil untuk meningkatkan kesejahteraan masyarakat, maka BUMN perlu berorientasi menghasilkan keuntungan. Di sisi lain, karena pengelolaan BUMN berdasarkan demokrasi ekonomi, maka aktivitas perekonomiannya perlu mengikuti mekanisme pasar (Avianti, 2006). Dengan demikian, BUMN perlu dikelola dan diawasi secara profesional. Selama ini, BUMN sering mendapat sorotan kritis dari masyarakat karena dipandang sebagai badan usaha yang tidak efisien, boros pemanfaatan sumber daya, sarat korupsi, dan memiliki profitabilitas rendah (Aprilina, 2013; Parimana \& Wisadha, 2015). Tabel 1 menunjukkan skor GCG (Good Corporate Governance) pada beberapa BUMN.

Tabel 1. Skor Implementasi GCG pada BUMN

\begin{tabular}{lccccc}
\hline \multirow{2}{*}{\multicolumn{1}{c}{ Nama Perusahaan }} & \multicolumn{5}{c}{ Skor Implementasi GCG } \\
\cline { 2 - 6 } & $\mathbf{2 0 1 3}$ & $\mathbf{2 0 1 4}$ & $\mathbf{2 0 1 5}$ & $\mathbf{2 0 1 6}$ & $\mathbf{2 0 1 7}$ \\
\hline PT Aneka Tambang (Persero), Tbk. & 88,92 & 97,04 & 97,57 & 97,86 & 97,01 \\
\hline PT Krakatau Steel (Persero), Tbk. & 77,80 & 82,46 & 87,13 & 89,01 & 89,66 \\
\hline PT Indofarma (Persero), Tbk. & 79,35 & 83,53 & 85,00 & 76,52 & 78,05 \\
\hline PT Garuda Indonesia (Persero), Tbk. & 90,30 & 91,37 & 92,61 & 92,75 & 92,76 \\
\hline PT LEN Industri (Persero) & 75,15 & 80,93 & 83,46 & 85,44 & 87,25 \\
\hline PT PLN (Persero) & 88,52 & 84,62 & 86,46 & 87,14 & 87,40 \\
\hline Sulyyyyy
\end{tabular}

Sumber: Annual report perusahaan tersebut untuk periode tahun 2013-2017. 
Berdasarkan Tabel 1, PT Aneka Tambang (Persero), Tbk. mendapatkan skor Good Corporate Governance (GCG) yang dinilai berdasarkan Keputusan Sekretaris Kementerian (Sekmen) BUMN RI SK-16/S.MBU/2012 di tahun 2013 sebesar 88,92 yang masuk dalam kategori sangat baik. Sepanjang tahun 2014-2016, PT Aneka Tambang (Persero), Tbk. mengalami peningkatan capaian skor GCG. Namun, skor capaian GCG tersebut menurun pada tahun 2017, jika dibandingkan dengan tahun sebelumnya menjadi 97,01. Sementara itu, PT Krakatau Steel (Persero), Tbk. juga memperoleh skor GCG yang cukup baik selama tahun 2014-2016. Pada tahun 2014, PT Krakatau Steel (Persero), Tbk. mendapatkan skor GCG sebesar 82,46 yang masuk ke dalam kategori baik. Peningkatan skor terjadi sepanjang tahun 2014-2017. Pada tahun 2017, skor implementasi GCG menunjukkan angka tertinggi, yaitu 89,66 yang masuk kedalam kategori baik. Namun, nilai implementasi GCG tersebut tidak sepadan dengan kinerja perusahaan.

Berdasarkan data tren penindakan kasus korupsi tahun 2017 yang dikeluarkan oleh Indonesian Corruption Watch (ICW) terdapat 23 kasus korupsi yang terjadi di lingkungan BUMN (Indonesian Corruption Watch, 2018). Praktik korupsi tersebut menghasilkan kerugian negara sebesar Rp2,8 triliun. Kasus-kasus korupsi di lingkungan BUMN juga sempat terjadi, seperti kasus megakorupsi E-KTP (Kartu Tanda Penduduk Elektronik) yang melibatkan direksi PT LEN Industri pada tahun 2016 (Rozie, 2019) dan korupsi pada proyek PLTU (Pembangkit Listrik Tenaga Uap) Riau-1 yang melibatkan Direksi PT PLN pada tahun 2018 (Ferdinan, 2019). Kasus-kasus tersebut mengindikasikan masih lemahnya implementasi Good Corporate Governance (GCG) di lingkungan BUMN. Ironisnya, perusahaan-perusahaan tersebut mendapatkan skor implementasi GCG yang baik sepanjang tahun 2014-2016.

Saat ini, banyak perusahaan merasa perlu melakukan diferensiasi dalam persaingan dan menawarkan produk yang memiliki nilai tambah secara eksklusif (Yin-Hsi, 2012). Di sisi lain, hal tersebut telah dilakukan oleh beberapa BUMN. Misalnya, PT Pindad, perusahaan yang bergerak di bidang manufaktur alat utama sistem pertahanan (alutsista). Saat ini, PT Pindad telah memproduksi dan bergerak di bidang industri yang menjual produk-produk alat-alat berat (PT Pindad, 2017). Selain itu, PT Telkom Indonesia (Persero), Tbk. juga melakukan pengembangan kegiatan usaha bukan hanya di bidang jaringan telekomunikasi, tetapi ia juga mulai menggarap bisnis digital lifestyle (Bastian, 2019). Pengembangan tersebut merupakan strategi yang diupayakan oleh perusahaan, yaitu memilih untuk membuat competitive advantage di pasar (Patel \& Cespedes, 2015).

PT Djakarta Lloyd (Persero) pernah melakukan transformasi yang mampu mengubah keadaan perusahaan dari rugi menjadi untung. BUMN pelayaran nasional ini awalnya mengalami stagnasi dalam perkembangan perusahaannya. Bahkan, perusahaan sempat berhenti beroperasi karena alat produksi yang tidak dapat diutilisasi. Kejadian tersebut merupakan kondisi keterpurukan perusahaan pada tahun 2008. Sepanjang tahun 2008-2011, perusahaan tersebut mengalami kerugian. Selanjutnya, perusahaan berhasil bangkit melalui diversifikasi muatan yang mengubah perusahaan dari rugi menjadi untung sebesar Rp70 miliar pada tahun 2018. Keuntungan tersebut lebih dari dua kali lipat keuntungan pada tahun 2017, yakni Rp37,5miliar. Melalui strategi diversifikasi tersebut, keadaan perusahaan telah berubah dan mendapatkan penghargaan Turn Around dari Kementerian BUMN RI (Purwadi, 2018a, 2018b). 
Kinerja organisasi merupakan hasil yang diperoleh organisasi dari implementasi strategi yang dipilih oleh pengelolanya (Child, 1997). Dengan kata lain, strategi yang dipilih oleh setiap perusahaan akan mempengaruhi kinerja perusahaan tersebut. Studi yang dilakukan oleh para peneliti (Volberda, Weerdt, Verwaal, Stienstra, \& Verdu 2012; Davies \& Walters, 2004; Child, Chung, \& Davies, 2003) menunjukkan bahwa strategi mempengaruhi kinerja perusahaan. Di samping itu, konten strategi yang dianut oleh suatu perusahaan juga dapat mempengaruhi kinerjanya (Meier, O'Toole, Boyne, \& Walker, 2006; Miles, Snow, Meyer, \& Coleman, 1978). Namun, kinerja perusahaan tidak semata-mata dipengaruhi oleh strategi yang dipilih. Studi yang dilakukan oleh Siswaji, Nuryartono, Arifin, dan Didu (2013) menunjukkan bahwa strategi tidak secara signifikan berpengaruh terhadap kinerja perusahaan. Oleh karena itu, penelitian ini bertujuan untuk mengidentifikasi pengaruh implementasi GCG dan strategi bisnis terhadap kinerja perusahaan.

\section{KAJIAN TEORITIS}

\section{Agency Theory}

Sebenarnya, permasalahan terkait corporate governance (dalam konteks korporasi) telah muncul sejak awal perusahaan berdiri (Sukamulja, 2004; Jensen \& Meckling, 1976) dan dapat digambarkan dengan agency theory. Di dalam konsep agency theory, manajemen perusahaan akan bertindak sebagai agent yang berfokus untuk memaksimalkan kepentingan mereka. Dengan demikian, agent kemungkinan tidak bertindak sesuai dengan kepentingan principal yang dikenal sebagai agency problem. Selain itu, konsep tersebut juga menyebutkan bahwa hasil dari tindakan agent yang tidak sesuai dengan kepentingan principal akan memicu munculnya agency costs dan asymmetric information (Jensen \& Meckling, 1976). Oleh karena itu, mekanisme corporate governance dapat digunakan untuk meminimalisasi permasalahan tersebut (Fitriastrini, 2017).

\section{Good Corporate Governance (GCG)}

GCG di lingkungan BUMN dikenal sebagai suatu proses dan struktur yang digunakan oleh organ BUMN untuk meningkatkan keberhasilan usaha dan akuntabilitas perusahaan untuk mewujudkan nilai pemegang saham dan stakeholder lainnya berlandaskan perundang-undangan dan nilai etika (Taspen, 2017). Proses tersebut dapat ditinjau melalui penegakan prinsip-prinsip GCG (Keputusan Menteri BUMN No. KEP117/M-MBU/2002). Sementara itu, GCG juga dapat ditinjau dari sisi pengendalian yang dapat dilihat dari kepemilikan institusional, kepemilikan manajerial, peran komite audit, dan komisaris independen (Fama \& Jensen, 1983). Berdasarkan corporate governance self-assessment checklist dari Forum for Corporate Governance in Indonesia (FCGI), implementasi GCG diukur melalui lima bidang, yaitu hak-hak pemegang saham, kebijakan corporate governance, praktik-praktik corporate governance, pengungkapan (disclosure), dan fungsi audit. Di lingkungan BUMN, self-assessment sendiri diatur dalam SK-16/S.MBU/2012 (Sekretaris Kementerian BUMN RI, 2012).

\section{Strategi Bisnis}

Strategi merupakan cara untuk mencapai tujuan organisasi (Porter, 1994; Barney, Wright, \& Ketchen, 2001; Peng, Sun, Pinkham, \& Chen, 2009). Dalam memilih strategi, pengelola perusahaan memperhatikan kondisi internal, seperti sumber daya dan kapabilitas perusahaan (Barney et al., 2001). Selain itu, kondisi lingkungan eksternal 
perusahaan juga mendapatkan perhatian (Pearce \& Robbins, 2008; Porter, 1994). Setiap tipe strategi yang digunakan pada suatu perusahaan akan menimbulkan perbedaan yang besar pada kinerja perusahaan (Ketchen, Thomas, \& McDaniel, 1996; Miles et al., 1978).

Miles et al. (1978) telah menemukan model strategi yang sangat komprehensif dalam penelitian di bidang manajemen. Model tersebut dikenal dengan typology of strategy yang telah dikenal luas dan menjadi salah satu teori manajemen strategi yang paling berpengaruh pada tiga dekade terakhir terkait dengan parsimony, industry-independence, dan korespondensi terhadap keadaan sesungguhnya (DeSarbo, DiBenedetto, Song, \& Sinha, 2005; Hambrick, 2003). Strategi manajerial yang diha-silkan oleh Miles et al. (1978) adalah prospector, analyzer, defender, dan reactor. Model tersebut merupakan model yang paling sering digunakan pada studi terkait strategi (Oyedijo \& Ro, 2012). Penggunaan model tersebut telah digunakan pada penelitian terkait perubahan intensitas Research and Development (Hambrick, 1983); kompetensi dan kinerja (Snow \& Hrebiniak, 1980); manufacturing and service strategies (Adam, 1983); dan pemilihan strategi (Burgelman, 1983).

\section{Kinerja Keuangan}

Kinerja keuangan merupakan hasil (outcome) yang diperoleh dari aktivitas usaha (Avianti, 2006). Aspek kinerja keuangan di dalam BUMN diukur berdasarkan Keputusan Menteri BUMN nomor Kep-100/MBU/2002 dengan menilai tingkat kesehatan BUMN. Rasio keuangan yang digunakan sebagai alat ukur adalah Return on Equity (ROE). ROE merupakan indikator yang komprehensif untuk mengukur kinerja perusahaan. Hal ini dikarenakan ROE menunjukkan indikasi seberapa baik manajer perusahaan mengelola dana investasi dari shareholders untuk memperoleh laba perusahaan (Healy, Bernard, \& Palepu, 2003). Dengan demikian, semakin besar nilai ROE, maka kinerja keuangan perusahaan menjadi semakin baik, karena imbal hasil terhadap modalnya besar. ROE digunakan pada penelitian ini, karena rasio tersebut menghitung profitabilitas perusahaan melalui net income.

\section{Kinerja Non-Keuangan}

Pada perusahaan modern, perhitungan kinerja operasional menjadi hal yang lebih penting, karena perusahaan yang menggunakan strategi cost leadership telah disaingi oleh strategi diferensiasi. Strategi ini berfokus pada fleksibilitas, kecepatan produksi, dan kualitas produk (Hayes \& Wheelright, 1984; Porter, 1980). Kinerja non-keuangan sering dinilai berdasarkan konsep Balanced Score Card. Konsep ini mengukur kinerja perusahaan melalui perspektif pelanggan, proses bisnis internal, dan program pengembangan dan pelatihan (Kaplan \& Norton, 1996).

Indeks kepuasan pelanggan digunakan pada penelitian ini untuk mengukur kinerja non-keuangan melalui perspektif pelanggan. Hal tersebut dilakukan, karena indeks kepuasan pelanggan memperhitungkan loyalitas dan kualitas pelanggan pada suatu perusahaan (Tuli \& Bharadwaj, 2009). Oleh karena itu, indeks kepuasan pelanggan ini juga mengukur seberapa jauh kesesuaian kualitas produk maupun jasa dengan ekspektasi pelanggan (Kim, Hong, \& Rho, 2013).

\section{Good Corporate Governance terhadap Kinerja Perusahaan}

Permasalahan perusahaan terkait implementasi corporate governance yang buruk telah tergambar pada agency theory yang dikemukakan oleh Jensen dan Meckling 
(1976) yang dikenal dengan agency problems. Masalah tersebut dapat membentuk suatu moral hazard, yaitu agent tidak berperan sebagaimana mestinya. Dengan menerapkan mekanisme corporate governance, masalah tersebut akan bisa dikurangi (Fitriastrini, 2017). Studi yang dilakukan oleh Brown dan Caylor $(2006,2009)$ menemukan bahwa perusahaan-perusahaan di Amerika Serikat yang tata kelolanya baik memiliki nilai ROE dan ROA yang lebih tinggi dibandingkan dengan perusahaan yang tata kelolanya buruk. Selain itu, Sami, Wang, dan Zhou (2011) juga menemukan bahwa implementasi GCG berpengaruh terhadap ROE. Dari uraian tersebut, hipotesis kesatu dirumuskan sebagai berikut:

H1: Implementasi GCG memiliki pengaruh terhadap kinerja perusahaan.

\section{Strategi Bisnis terhadap Kinerja Perusahaan}

Saat ini, beberapa studi yang telah dilakukan berkaitan dengan strategi bisnis bertujuan untuk mengembangkan pemahaman tentang hubungan penerapan strategi bisnis terhadap kinerja perusahaan. Perbedaan pada kinerja di berbagai macam tipe strategi terjadi karena adanya nature lingkungan yang bervariasi. Pengukuran kinerja yang berbeda juga sangat mempengaruhi perbedaan tersebut (Anwar, Shah, \& Hasnu, 2016). Sebagai contoh, current profitability yang dihasilkan oleh defenders dapat mengungguli prospectors. Di sisi lain, prospectors juga dapat mengungguli defenders dalam hal market share (Hambrick, 1983). Beberapa studi menunjukkan bahwa defenders, analyzers, dan prospectors jauh mengungguli reactors (Snow \& Hrebiniak, 1980; Smith, Guthrie, \& Chen, 1986, 1989; Parnell \& Wright, 1993; Parnell, 2010; Parnell, Koseoglu, Long, \& Spillan, 2012).

H2: Implementasi strategi bisnis memiliki pengaruh terhadap kinerja perusahaan.

Berdasarkan uraian dan penjelasan tersebut, maka hubungan antarvariabel dalam penelitian ini ditunjukkan pada model penelitian pada Gambar 1.

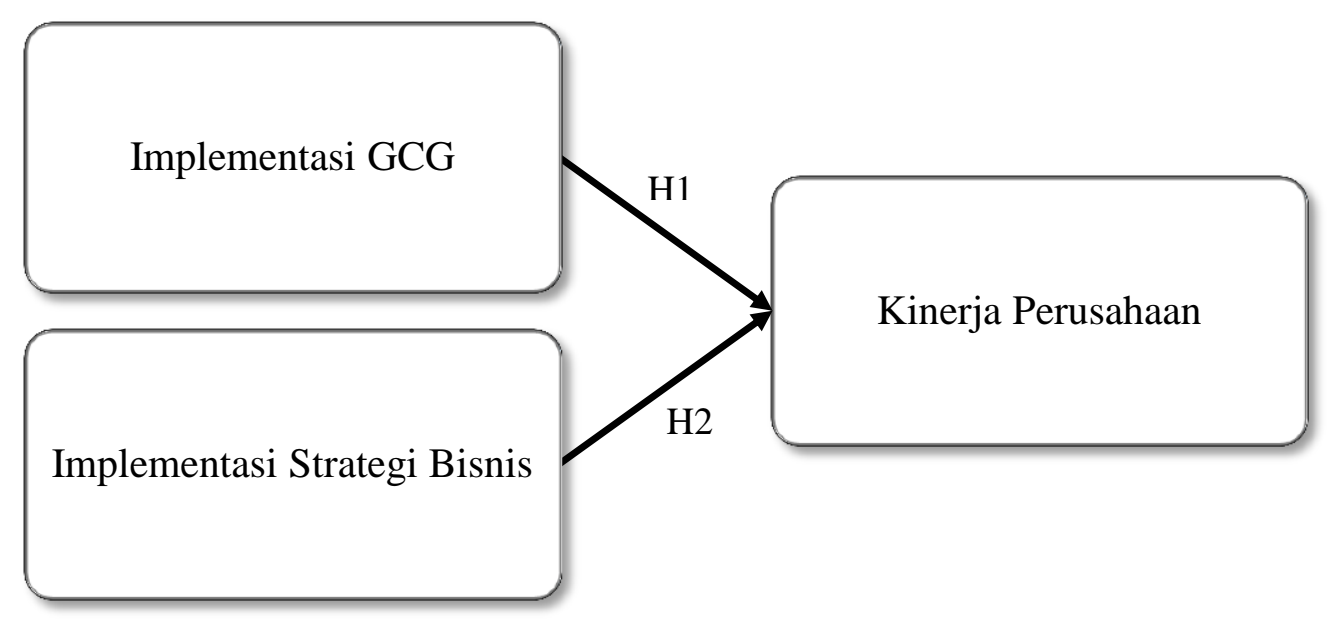

Gambar 1. Model Penelitian 


\section{METODE PENELITIAN}

Penelitian ini merupakan penelitian kuantitatif. Pengujian hipotesis pada penelitian ini menggunakan uji parsial (uji-t) dengan maksud untuk mengetahui pengaruh antara variabel dependen terhadap variabel independen. Selain itu, penelitian ini menggunakan regresi data panel dan melakukan penentuan model estimasi, serta uji asumsi klasik. Persamaan regresi pada penelitian ini ditunjukkan pada persamaan [1].

$$
\mathbf{Y}=\mathbf{a}+\boldsymbol{\beta}_{1} \mathbf{X}_{1}+\boldsymbol{\beta}_{2} \mathbf{X}_{2}
$$

Pada persamaan regresi tersebut [1], $\mathrm{Y}$ adalah kinerja perusahaan, a merupakan konstanta, serta $X_{1}$ dan $X_{2}$ masing-masing merupakan variabel implementasi GCG dan imple-mentasi strategi bisnis, sedangkan $\beta 1$ dan $\beta 2$ adalah koefisien regresi.

\section{Data dan Sampel}

Data yang digunakan pada penelitian ini adalah data sekunder yang bersifat kuantitatif berupa rasio dan skor yang diperoleh dari laporan tahunan perusahaan yang sudah diaudit pada tahun 2013 hingga 2018. Sampel pada penelitian ini adalah 22 BUMN yang memenuhi kriteria seperti yang ditunjkkan pada Tabel 2.

Tabel 2. Kriteria Sampel Penelitian

\begin{tabular}{clc}
\hline No & \multicolumn{1}{c}{ Keterangan } & $\begin{array}{c}\text { Jumlah } \\
\text { Perusahaan }\end{array}$ \\
\hline 1 & Jumlah BUMN & 118 \\
\hline 2 & $\begin{array}{l}\text { Jumlah BUMN yang tidak mempublikasikan laporan tahunan secara lengkap } \\
\text { pada periode tahun 2013-2018 }\end{array}$ & $(57)$ \\
3 & Jumlah BUMN yang berbentuk Perum (Perusahaan Umum) & $(14)$ \\
\hline 4 & Jumlah BUMN yang merupakan industri keuangan dan asuransi & $(19)$ \\
\hline 5 & $\begin{array}{l}\text { Jumlah BUMN yang tidak mencantumkan indeks kepuasan pelanggan pada } \\
\text { laporan tahunan periode 2013-2018 }\end{array}$ & $(6)$ \\
\hline 6 & Jumlah sampel & 22 \\
\hline
\end{tabular}

Sumber: Sekretaris Kementerian BUMN RI, SK-16/MBU/01/2016.

\section{Variabel Independen}

\section{a. Implementasi Good Corporate Governance (GCG)}

Implementasi GCG pada penelitian ini digambarkan dengan skor GCG melalui selfassessment yang telah diatur dalam Keputusan Sekmen BUMN RI nomor SK16/MBU/2012. Skor GCG yang telah diperoleh akan diklasifikasikan sebagaimana telah diatur dalam SK-16/MBU/2012 tersebut dengan pengelompokannya pada Tabel 3.

Tabel 3.Klasifikasi Implementasi GCG melalui Self-assessment

\begin{tabular}{cl}
\hline Skor & \multicolumn{1}{c}{ Klasifikasi } \\
\hline$>85$ & Sangat Baik \\
$75-85$ & Baik \\
\hline $60-75$ & Cukup Baik \\
\hline $50-60$ & Kurang Baik \\
\hline$<50$ & Tidak Baik \\
\hline
\end{tabular}

Sumber: Sekmen BUMN RI, SK-16/MBU/2012. 


\section{b. Implementasi Strategi Bisnis}

Pada penelitian ini, pengelompokkan implementasi strategi bisnis suatu perusahaan dilakukan dengan mengukur beberapa rasio, seperti yang pernah dilakukan oleh Ittner, Larcker, dan Rajan (1997) dan menambahkan pengukuran berdasarkan teori Miles et al. (1978), serta hasil empiris penelitian Hambrick (1983). Pengukuran rasio tersebut dihitung dari nilai rasio selama minimal lima tahun (Ittner et al., 1997). Rasio-rasio yang digunakan dalam penelitian ini adalah:

\section{Employee to Sales Ratio (EMPSAL)}

Semakin besar EMPSAL, maka sebuah perusahaan dapat dikatakan fokus pada efisiensi dan hal tersebut sesuai dengan strategi defender (Hambrick, 1983). Rasio ini dihitung menggunakan rumus pada persamaan [2].

$$
\text { EMPSAL }=\frac{\text { Jumlah pegawai }}{\text { Penjualan }}
$$

\section{Market to Book Ratio (MTBR)}

Semakin besar MTBR, maka sebuah perusahaan dikatakan memiliki fokus terhadap pertumbuhan perusahaan. Hal tersebut sesuai dengan karakteristik strategi prospector (Miles et al., 1978; Hambrick, 1983; Ittner et al., 1997). Rasio ini dihitung dengan rumus pada persamaan [3].

$$
M T B R=\frac{\text { Kapitalisasi Pasar }}{\text { Total Nilai Buku }}
$$

\section{Marketing Expense to Sales Ratio (METSR)}

Semakin besar METSR, maka sebuah perusahaan dapat dikatakan cenderung lebih berfokus pada inovasi produk maupun jasa yang baru atau pencarian pangsa pasar yang baru. Hal tersebut sesuai dengan karakteristik prospector (Miles et al., 1978; Hambrick, 1983; Ittner et al., 1997). Rasio ini dihitung menggunakan rumus pada persamaan [4].

$$
\text { METSR }=\frac{\text { Beban Penjualan }}{\text { Penjualan }}
$$

\section{Research and Development to Sales Ratio (R\&DS)}

Semakin besar R\&DS, maka sebuah perusahaan disebut memiliki kecenderungan membuat produk-produk baru sesuai dengan karakteristik prospector (Miles et al., 1978; Hambrick, 1983). Rasio tersebut dihitung dengan rumus yang ditunjukkan pada persamaan [5].

$$
R \& D S=\frac{\text { Biaya riset dan pengembangan }}{\text { Penjualan }}
$$

\section{Plant, Property, and Equipment Intensity Ratio (PPEINT)}

Semakin besar PPEINT, maka sebuah perusahaan dikatakan berfokus pada efisiensi aset produksi yang digunakan dan hal tersebut sesuai dengan karakteristik defender (Miles et al., 1978; Hambrick, 1983). Rasio tersebut dihitung dengan menggunakan rumus pada persamaan [6]. 


$$
\text { PPEINT }=\frac{\text { Plant, } \text { Property, and Equipment }}{\text { Total Assets }}
$$

Setelah menghitung nilai rasio-rasio tersebut, pemeringkatan dan pemberian skor dilakukan berdasarkan urutan kuintil. Untuk empat rasio awal, yaitu EMPSAL, MTBR, METSR, dan R\&DS, maka setiap perusahaan yang menduduki urutan pada kuintil teratas akan mendapatkan skor 5, kuintil selanjutnya akan mendapatkan skor 4, dan seterusnya. Pemberian skor pada rasio PPEINT dilakukan melalui inverted scoring, karena strategi defenders cenderung memiliki intensitas aset tetap yang tinggi (Higgins, Omer, \& Phillips, 2011), sehingga perusahaan yang menduduki kuintil teratas menda-patkan skor 1, kuintil selanjutnya akan mendapatkan skor 2, dan seterusnya. Maksimal skor yang dapat diperoleh setiap perusahaan adalah 25. Perusahaan yang mendapatkan skor implementasi strategi bisnis antara 5-10 dikategorikan ke dalam strategi defender, skor antara 20-25 dikategorikan ke dalam strategi prospector. Selanjutnya, perusahaan yang mendapatkan skor di antara kategori defender dan prospector secara langsung dikategorikan ke dalam strategi analyzer (Higgins et al., 2011).

\section{Variabel Dependen}

Kinerja keuangan perusahaan diproksikan menggunakan ROE. Penggunaan dan pengukuran proksi tersebut mengikuti penelitian yang dilakukan oleh Sarac, Ertan, dan Yucel (2014) dan Anwar et al. (2016) dengan rumus pada persamaan [7].

$$
\text { ROE }=\frac{\text { Laba bersih }}{\text { Total ekuitas }}
$$

Kinerja non-keuangan perusahaan yang digunakan pada penelitian ini mengikuti peneli-tian Sun dan Kim (2013) yang diukur menggunakan Customer Satisfaction Index (CSI) yang tertera pada laporan tahunan perusahaan.

\section{HASIL DAN PEMBAHASAN}

Tabel 4 menunjukkan bahwa uji Chow pada model ROE menghasilkan angka prob lebih kecil daripada nilai $F(0,05)$, sehingga kesimpulannya adalah model estimasi penelitian ini menggunakan fixed effect model.

\section{Tabel 4. Hasil Uji Chow pada Model ROE}

\begin{tabular}{lllll}
\hline Dependent Variable: ROE & & & \\
Method: Panel Least Squares & & & \\
Date: $12 / 05 / 19$ Time: $16: 48$ & & & \\
Sample: 2013 2018 & & & \\
Periods included: 6 & & & \\
Cross-sections included: 22 & & & \\
Total panel (balanced) observations: 132 & & & \\
Redundant Fixed Effects Tests & Statistic & Prob. \\
Equation: Untitled & 20.037636 & $(21,106)$ & 0.0000 \\
Test cross-section fixed effects & 211.643990 & 21 & 0.0000 \\
\hline \hline
\end{tabular}

Sumber: Data penelitian diolah menggunakan software eviews 9. 
Tabel 5 menunjukkan bahwa uji Hausman pada model ROE menunjukkan angka prob lebih besar daripada nilai $\mathrm{F}(0,05)$, sehingga kesimpulannya adalah model estimasi penelitian ini menggunakan random effect model.

Tabel 5. Hasil Uji Hausman pada Model ROE

\begin{tabular}{|c|c|c|c|}
\hline \multicolumn{4}{|c|}{$\begin{array}{l}\text { Dependent Variable: ROE } \\
\text { Method: Panel EGLS (Cross-section r } \\
\text { Date: } 12 / 05 / 19 \text { Time: } 16: 49 \\
\text { Sample: } 20132018 \\
\text { Periods included: } 6 \\
\text { Cross-sections included: } 22 \\
\text { Total panel (balanced) observations: } 1 \\
\text { Swamy and Arora estimator of compo } \\
\text { Correlated Random Effects - Hausmar } \\
\text { Equation: Untitled } \\
\text { Test cross-section random effects }\end{array}$} \\
\hline Test Summary & Chi-Sq. Statistic & Chi-Sq. d.f. & Prob. \\
\hline Cross-section random & 7.020739 & 4 & 0.1348 \\
\hline
\end{tabular}

Sumber: Data penelitian diolah menggunakan software eviews 9.

Uji Lagrange Multiplier pada model ROE ditunjukkan pada Tabel 6 dan menghasilkan angka prob lebih besar daripada $\mathrm{F}(0,05)$ yang berarti bahwa model estimasi penelitian ini menggunakan random effect model.

\section{Tabel 6. Hasil Uji Lagrange Multiplier pada Model ROE}

\begin{tabular}{|c|c|c|c|}
\hline \multicolumn{4}{|c|}{$\begin{array}{l}\text { Dependent Variable: ROE } \\
\text { Method: Panel Least Squares } \\
\text { Date: } 12 / 05 / 19 \text { Time: } 16: 50 \\
\text { Sample: } 20132018 \\
\text { Periods included: } 6 \\
\text { Cross-sections included: } 22 \\
\text { Total panel (balanced) observations: } 132 \\
\text { Lagrange Multiplier Tests for Random Effects } \\
\text { Null hypotheses: No effects } \\
\text { Alternative hypotheses: Two-sided (Breusch-Pagan) and one-sided } \\
\quad \text { (all others) alternatives }\end{array}$} \\
\hline & \multicolumn{3}{|c|}{ Test Hypothesis } \\
\hline & Cross-section & Time & Both \\
\hline Breusch-Pagan & $\begin{array}{l}162.5712 \\
(0.0000)\end{array}$ & $\begin{array}{l}0.013723 \\
(0.9067)\end{array}$ & $\begin{array}{l}162.5849 \\
(0.0000)\end{array}$ \\
\hline
\end{tabular}

Sumber: Data penelitian diolah menggunakan software eviews 9.

Pengujian yang sama dilakukan juga pada model CSI melalui uji Chow pada Tabel 7 yang menghasilkan angka prob lebih besar daripada nilai $\mathrm{F}(0,05)$, sehingga model CSI penelitian ini menggunakan fixed effect model. 
Tabel 7. Hasil Uji Chow pada Model CSI

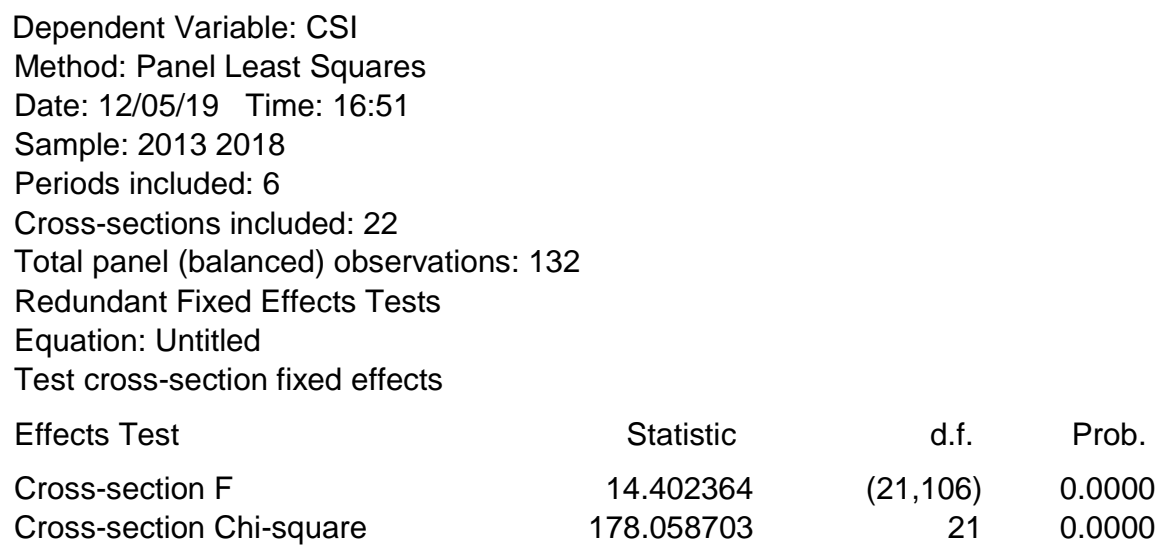

Sumber: Data penelitian diolah menggunakan software eviews 9.

Selain itu, hasil uji Hausman pada model CSI ditunjukkan pada Tabel 8. Hasil uji Hausman tersebut menunjukkan bahwa angka prob lebih besar daripada nilai $\mathrm{F}(0,05)$. Hasil tersebut menunjukkan bahwa model CSI menggunakan random effect model.

Tabel 8. Hasil Uji Hausman pada Model CSI

\begin{tabular}{|c|c|c|c|}
\hline \multicolumn{4}{|c|}{$\begin{array}{l}\text { Dependent Variable: CSI } \\
\text { Method: Panel EGLS (Cross-section random effects) } \\
\text { Date: } 12 / 05 / 19 \text { Time: } 16: 51 \\
\text { Sample: } 20132018 \\
\text { Periods included: } 6 \\
\text { Cross-sections included: } 22 \\
\text { Total panel (balanced) observations: } 132 \\
\text { Swamy and Arora estimator of component variances } \\
\text { Correlated Random Effects - Hausman Test } \\
\text { Equation: Untitled } \\
\text { Test cross-section random effects }\end{array}$} \\
\hline Test Summary & $\begin{array}{l}\text { Chi-Sq. } \\
\text { Statistic }\end{array}$ & Chi-Sq. d.f. & Prob. \\
\hline Cross-section random & 2.181382 & 4 & 0.7024 \\
\hline
\end{tabular}

Sumber: Data penelitian diolah menggunakan software eviews 9.

Karena bentuk model estimasi pada model CSI belum dapat disimpulkan, maka pengujian lagrange multiplier dilakukan dengan hasilnya ditunjukkan pada Tabel 9. Hasil uji tersebut menunjukkan angka prob lebih besar daripada $\mathrm{F}(0,05)$ yang dapat disimpulkan bahwa model CSI menggunakan random effect model. Setelah melakukan ketiga pengujian terhadap kedua model penelitian, maka kesimpulannya adalah kedua model penelitian ini menggunakan random effect model sesuai dengan yang ditunjukkan pada Tabel 10. 


\section{Tabel 9. Hasil Uji Lagrange Multiplier pada Model CSI}

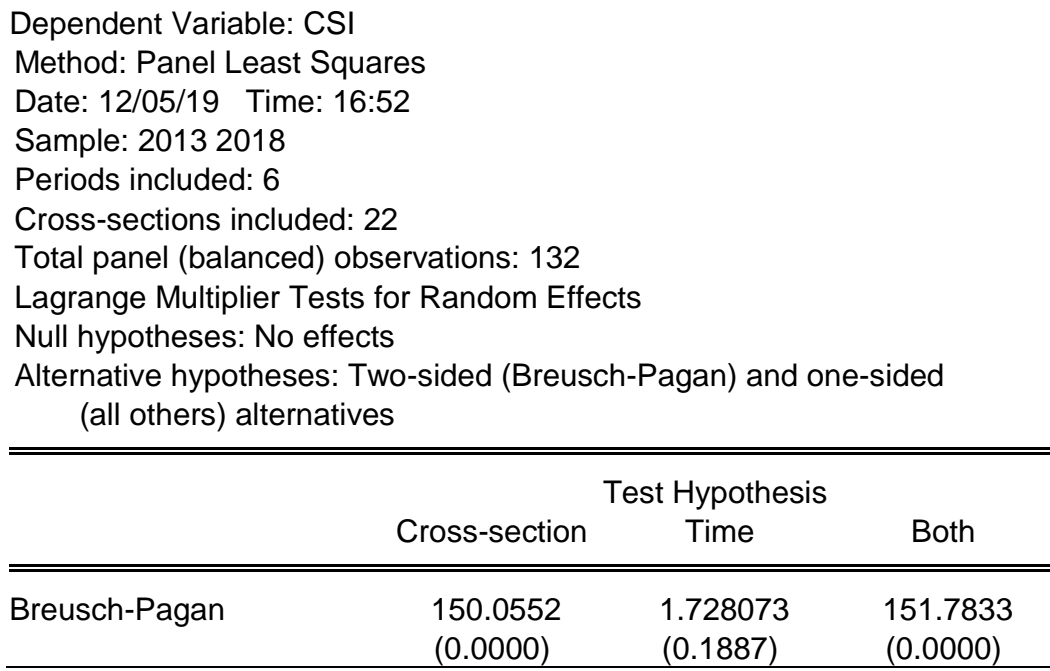

Sumber: Data penelitian diolah menggunakan software eviews 9.

Tabel 10. Hasil Rekapitulasi Pemilihan Model Regresi Data Panel

\begin{tabular}{lllll}
\hline Model & Chow Test & Hausman Test & Lagrange Multiplier Test & Kesimpulan \\
\hline ROE & Fixed Effect & Random Effect & Random Effect & Random Effect \\
\hline CSI & Fixed Effect & Random Effect & Random Effect & Random Effect \\
\hline
\end{tabular}

Sumber: Data penelitian yang diolah (2019).

Setelah melakukan uji estimasi model, data penelitian ini juga diuji dengan asumsi klasik yang terdiri atas uji autokorelasi dan heteroskedastisitas. Tabel 11 menunjukkan hasil uji autokorelasi. Angka Durbin-Watson pada setiap model penelitian masingmasing bernilai 1,977474 dan 1,994970 yang menunjukkan tidak adanya masalah autokorelasi pada setiap model penelitian tersebut. Selanjutnya, Tabel 12 menunjukkan hasil uji heteroskedastisitas untuk setiap model penelitian. Angka $O b s * R$-squared pada setiap model masing-masing memiliki nilai di atas $\alpha(0,05)$, yaitu 2,529604 dan 7,092061. Hasil tersebut dapat diartikan bahwa tidak terdapat masalah heteroskedastisitas pada kedua model penelitian.

Setelah melakukan uji asumsi klasik, data penelitian ini dilakukan uji regresi dengan menggunakan random effect model sesuai dengan model yang telah dipilih berdasarkan pengujian estimasi model. Tabel 13 menunjukkan hasil uji regresi pada model ROE, sedangkan Tabel 14 menunjukkan hasil uji regresi pada model CSI. Kedua tabel tersebut masing-masing menerangkan arah dan signifikansi pengaruh variabel GCG dan STRATEGI terhadap variabel ROE maupun CSI. Arah pengaruh dapat dilihat dari nilai koefisien, sedangkan signifikansinya dapat dilihat dari nilai prob. Saat nilai koefisien bersifat positif, maka pengaruh yang dihasilkan oleh variabel tersebut memiliki hubungan yang searah. Sebaliknya, apabila koefisien bersifat negatif, maka pengaruhnya memiliki hubungan yang berlawanan. Di sisi lain, jika nilai prob lebih kecil dari nilai alpha $(<5 \%)$, maka variabel tersebut menghasilkan pengaruh yang signifikan, atau sebaliknya. 
Tabel 11. Hasil Uji Autokorelasi pada Model ROE dan CSI

Dependent Variable: ROE

Total panel (balanced) observations: 132

Presample missing value lagged residuals set to zero.

\begin{tabular}{lllr}
\hline \hline R-squared & 0.427141 & Mean dependent var & $4.44 \mathrm{E}-17$ \\
Adjusted R-squared & 0.399644 & S.D. dependent var & 0.088553 \\
S.E. of regression & 0.068613 & Akaike info criterion & -2.469099 \\
Sum squared resid & 0.588467 & Schwarz criterion & -2.316223 \\
Log likelihood & 169.9606 & Hannan-Quinn criter. & -2.406978 \\
F-statistic & 15.53399 & Durbin-Watson stat & 1.977474 \\
Prob(F-statistic) & 0.000000 & & \\
\hline \hline
\end{tabular}

Dependent Variable: CSI

Total panel (balanced) observations: 132

Presample missing value lagged residuals set to zero.

\begin{tabular}{lllr}
\hline \hline R-squared & 0.447792 & Mean dependent var & $-6.50 \mathrm{E}-17$ \\
Adjusted R-squared & 0.421286 & S.D. dependent var & 0.082527 \\
S.E. of regression & 0.062781 & Akaike info criterion & -2.646750 \\
Sum squared resid & 0.492685 & Schwarz criterion & -2.493874 \\
Log likelihood & 181.6855 & Hannan-Quinn criter. & -2.584628 \\
F-statistic & 16.89402 & Durbin-Watson stat & 1.994970 \\
Prob(F-statistic) & 0.000000 & & \\
\hline \hline
\end{tabular}

Sumber: Data penelitian diolah menggunakan software eviews 9.

Tabel 12. Hasil Uji Heteroskedastisitas pada Model ROE dan CSI

\begin{tabular}{llll}
\hline Heteroskedasticity Test: Breusch-Pagan-Godfrey & \\
\hline \hline F-statistic & 0.620334 & Prob. F(4,127) & 0.6488 \\
Obs*R-squared & 2.529604 & Prob. Chi-Square(4) & 0.6393 \\
Scaled explained SS & 25.40980 & Prob. Chi-Square(4) & 0.0000 \\
\hline \hline
\end{tabular}

Heteroskedasticity Test: Breusch-Pagan-Godfrey

\begin{tabular}{llll}
\hline \hline F-statistic & 1.802711 & Prob. F(4,127) & 0.1323 \\
Obs*R-squared & 7.092061 & Prob. Chi-Square(4) & 0.1311 \\
Scaled explained SS & 18.40614 & Prob. Chi-Square(4) & 0.0010 \\
\hline \hline
\end{tabular}

Sumber: Data penelitian diolah menggunakan software eviews 9.

\section{Uji Regresi terhadap Kinerja Keuangan}

Berdasarkan Tabel 15 untuk model ROE, variabel implementasi GCG (GCG) maupun strategi bisnis (STRATEGI) memiliki nilai $\beta \geq 0$, sedangkan $p$-value untuk masing-masing variabel berbeda. Pada variabel GCG, $p$-value bernilai 0,92222 lebih besar daripada alpha 5\%, sedangkan variabel STRATEGI memiliki p-value 0,00750 atau lebih kecil daripada alpha 5\%. Dengan demikian, implementasi GCG memiliki pengaruh positif, tetapi tidak signifikan terhadap kinerja keuangan perusahaan, sedangkan implementasi strategi bisnis memiliki pengaruh positif dan signifikan terhadap kinerja perusahaan. 
Tabel 13. Hasil Random Effect Model pada ROE

Dependent Variable: ROE

Method: Panel EGLS (Cross-section random effects)

Date: 12/05/19 Time: 16:49

Sample: 20132018

Periods included: 6

Cross-sections included: 22

Total panel (balanced) observations: 132

Swamy and Arora estimator of component variances

\begin{tabular}{ccccc}
\hline \hline Variable & Coefficient & Std. Error & t-Statistic & Prob. \\
\hline \hline C & 0.034238 & 0.105880 & 0.323361 & 0.7470 \\
GCG & 0.000118 & 0.001211 & 0.097864 & 0.9222 \\
STRATEGI & 0.008997 & 0.003311 & 2.717496 & 0.0075 \\
\hline
\end{tabular}

Sumber: Data penelitian diolah menggunakan software eviews 9.

Tabel 14. Hasil Random Effect Model pada CSI

Dependent Variable: CSI

Method: Panel EGLS (Cross-section random effects)

Date: 12/05/19 Time: 16:51

Sample: 20132018

Periods included: 6

Cross-sections included: 22

Total panel (balanced) observations: 132

Swamy and Arora estimator of component variances

\begin{tabular}{ccccc}
\hline \hline Variable & Coefficient & Std. Error & t-Statistic & Prob. \\
\hline \hline C & 0.466264 & 0.109145 & 4.271982 & 0.0000 \\
GCG & 0.001344 & 0.001261 & 1.066081 & 0.2884 \\
STRATEGI & 0.007978 & 0.003323 & 2.400753 & 0.0178
\end{tabular}

Sumber: Data penelitian diolah menggunakan software eviews 9.

Hasil pengujian ini sejalan dengan penelitian Akdogan dan Boyacioglu (2014), serta Gompers, Ishii, dan Metrick (2003). Hal tersebut dapat terjadi karena praktik GCG dapat membuat image suatu perusahaan menjadi baik, sehingga para investor terkesan melihatnya less risky. Selain itu, implementasi GCG membuat perusahaan dapat menyebarkan rate of return dari pemilik perusahaan yang membuat perusahaan seakan-akan lebih valuable di mata investor. Di sisi lain, perusahaan yang mengimplementasi GCG dianggap lebih memiliki arus kas yang baik di masa depan (Jensen \& Meckling, 1976).

Tabel 15. Hasil Uji Regresi Data Panel terhadap ROE

\begin{tabular}{|c|c|c|c|c|}
\hline Model & Variabel & Koefisien & Prob. & Kesimpulan \\
\hline \multirow{3}{*}{ ROE } & $\mathrm{C}$ & 0,03424 & 0,74700 & \\
\hline & GCG & 0,00012 & 0,92222 & Tidak Signifikan \\
\hline & STRATEGI & 0,00899 & 0,00750 & Signifikan \\
\hline
\end{tabular}

Sumber: Data diolah (2019). 
Senada dengan Ittner et al. (1997), beberapa penilaian yang dilakukan untuk menentukan implementasi strategi bisnis pada suatu perusahaan di antaranya adalah inovasi perusahaan. Inovasi produk maupun proses pada suatu perusahaan memiliki pengaruh yang positif terhadap ROE (Canh, Liem, Thu, \& Khuong, 2019; GonzalezFernandez \& Gonzalez-Velasco, 2018). Hal tersebut terjadi akibat efek yang diberikan perusahaan terhadap investor yang ingin berspekulasi. Banyaknya inovasi yang dilakukan oleh perusahaan membuat investor gencar untuk berinvestasi pada R\&D (Research and Development) perusahaan. Di sisi lain, karena sumber daya secara umum terbatas dan upaya kerja sama dengan pihak eksternal membutuhkan dana yang besar (Lin, 2013; Duysters \& Lokhsin, 2011), perusahaan akan melakukan open innovation yang dapat menimbulkan gencarnya aktivitas $R \& D$ pada suatu perusahaan.

Gencarnya aktivitas R\&D oleh perusahaan yang dapat membuat banyaknya investasi masuk pada aktivitas tersebut membuat perusahaan mendapatkan kemungkinan unexpected earning di masa depan. Hal tersebut dapat menjadi daya tarik bagi investor. Dengan demikian, banyaknya $R \& D$ dan inovasi yang dilakukan oleh perusahaan akan meningkatkan pangsa pasarnya juga. Di saat yang bersamaan, daya saing perusahaan dapat meningkat dan membuatnya memperoleh laba yang lebih banyak dengan meminimalisasi persaingan.

\section{Uji Regresi terhadap Kinerja Non-Keuangan}

Tabel 16 menunjukkan bahwa implementasi GCG berpengaruh positif, tetapi tidak signifikan terhadap CSI. Hasil ini sesuai dengan studi yang dilakukan oleh Nugraheni dan Fauziah (2019). GCG memiliki peran penting dalam meningkatkan hubungan antara manajemen perusahaan dan stakeholder (misalnya konsumen). Pada akhirnya, hubungan yang baik tersebut akan membuat kinerja perusahaan meningkat. Konsumen memiliki ekspektasi yang tinggi pada produk atau jasa sesuai dengan waktu dan uang yang mereka keluarkan dalam rangka upaya untuk memperoleh barang atau jasa tersebut. Implementasi GCG dapat meningkatkan kinerja pada sebuah industri untuk menyediakan produk dan jasa yang lebih berkualitas. Hasil ini menjadikan implementasi GCG dapat meningkatkan kepuasan pelanggan maupun membangun loyalitas mereka.

Tabel 16. Hasil Uji Regresi Data Panel terhadap CSI

\begin{tabular}{|c|c|c|c|c|}
\hline Model & Variabel & Koefisien & Prob. & Kesimpulan \\
\hline \multirow{3}{*}{ CSI } & $\mathrm{C}$ & 0,46626 & 0,00000 & \\
\hline & $\mathrm{GCG}$ & 0,00134 & 0,28840 & Tidak Signifikan \\
\hline & STRATEGI & 0,00798 & 0,01780 & Signifikan \\
\hline
\end{tabular}

Sumber: Data diolah (2019).

Berdasarkan hasil pada Tabel 16 tersebut, implementasi strategi bisnis akan berpengaruh positif dan signifikan terhadap CSI. Hal ini sejalan dengan studi yang dilakukan oleh Daragahi (2017); Naveed, Akhtar, dan Cheema (2013); serta Hitt, Hoskisson, dan Kim (1997). Inovasi digunakan oleh perusahaan sebagai orientasi strategi terhadap kepuasan pelanggan, loyalitas pelanggan, dan mendapatkan pasar potensial yang mampu meningkatkan pangsa pasar (Pan \& Zinkhan, 2006). Inovasi dapat berupa produk baru maupun konsep baru yang ditawarkan dari riset yang sistematis. Produk maupun 
konsep baru tersebut memiliki kualitas yang spesifik dan dapat memuaskan pelanggan. Secara sederhana, ketika produk baru muncul dengan fitur-fitur baru, maka konsumen akan merasa tertarik untuk mendapatkan produk tersebut. Pada saat produk mampu memuaskan konsumen, mereka cenderung akan membelinya lagi.

\section{KESIMPULAN DAN SARAN}

Implementasi GCG dan strategi bisnis memiliki pengaruh positif terhadap kinerja keuangan maupun non-keuangan pada BUMN di Indonesia. Oleh karena itu, semakin baik implementasi GCG dan strategi bisnis pada BUMN di Indonesia akan meningkatkan kinerja keuangan maupun non-keuangan perusahaan tersebut. BUMN di Indonesia perlu menerapkan strategi bisnis analyzer, yaitu strategi dengan karakteristik selalu berupaya untuk meminimalisasi risiko sambil memaksimalkan kesempatan untuk mendapatkan keuntungan. Strategi ini biasanya menjadi pioneer dalam pembuatan produk baru. Namun, perusahaan harus tetap mengamati kompetitor lain dengan cara sering masuk ke pasar membawa produk maupun jasa yang superior dengan biaya yang lebih efisien.

Oleh karena itu, inovasi maupun perolehan pangsa pasar baru perlu dilakukan perusahaan agar dapat lebih meningkatkan daya saing untuk memasarkan dan mendistribusikan produk maupun jasanya kepada konsumen. Di sisi lain, BUMN juga tetap perlu memperhatikan para kompetitor lain sebelum mengambil langkah inovasi sebagai tolok ukur melakukan inovasi baru, sehingga tingkat risiko kegagalan dalam inovasi produk maupun jasa dapat diminimalisasi demi menyesuaikan strategi yang akan diimplementasikan di kemudian hari. Dengan demikian, BUMN diharapkan mampu memenangkan persaingan di pasar bebas. Untuk penelitian selanjutnya, penggunaan periode analisis dapat diperbarui sesuai kondisi terkini. Selain itu, penelitian ini masih terbatas dalam upaya menganalisis BUMN, sehingga sampel pada penelitian mendatang disarankan untuk dapat ditambah atau diperluas agar dapat mencakup strategi bisnis pada perusahaan swasta juga.

\section{DAFTAR REFERENSI}

Adam, E. (1983). Towards a Typology of Production and Operations Management Systems. Academic of Management Review, 8(2), 365-375.

Akdogan, Y. E. \& Boyacioglu, M. A. (2014). The Effect of Corporate Governance on Firm Performance: A Case of Turkey. International Journal Critical Accounting, 6(2), 187-210.

Anwar, J., Shah, S., \& Hasnu, S. (2016). Business Strategy and Organizational Performance: Measures and Relationships. Pakistan Economic and Social Review, 97122.

Aprilina, V. (2013). Dampak Privatisasi pada Kinerja Keuangan Badan Usaha Milik Negara (BUMN) di Indonesia. JRAK, 4(1), 1-12.

Avianti, I. (2006). Privatisasi BUMN dan Penegakan Good Corporate Governance dan Kinerja BUMN. Kinerja, 10(1), 57-65.

Barney, J., Wright, M., \& Ketchen, D. (2001). The Resource-based View of the Firm: Ten Years After 1991. Journal of Management, 27(6), 625-641. 
Bastian, E. (2019). Industri. Retrieved from www.industri.kontan.co.id: https://industri. kontan.co.id/news/telkom-indonesia-tlkm-akan-fokus-garap-bisnis-digital-life style-tahun-ini (Januari 14).

Brown, L. D. \& Caylor, M. L. (2006). Corporate Governance and Firm Valuation. Journal of Accounting Public Policy, 25, 409-434.

Brown, L. D. \& Caylor, M. L. (2009). Corporate Governance and Firm Operating Performance. Review of Quantitative Finance and Accounting, 32(2), 129-144.

Bumn.go.id (2017). Taspen. Retrieved from http://www.bumn.go.id/taspen/halaman/ 127 (18 Desember).

Burgelman, R. A. (1983). Corporate Entrepreneurship and Strategic Management: Insights from a Process Study. Management Science, 29(1), 349-364.

Canh, N. T., Liem, N. T., Thu, P. A., \& Khuong, N. V. (2019). The Impact of Innovation on the Firm Performance and Corporate Social Responsibility of Vietnamese Manufacturing Firms. Sustainability, 11, 1-14.

Child, J. (1997). Strategic Choice in the Analysis of Action, Structure, Organizations, and Environment: Retrospect and Prospect. Organization Studies, 18(1), 43-76.

Child, J., Chung, L., \& Davies, H. (2003). The Performance of Cross-Border Units in China: A Test of Natural Selection, Strategic Choice, and Contingency Theories. Journal of International Business Studies, 34, 242-254.

Davies, H. \& Walters, P. (2004). Emergent Patterns of Strategy, Environment, and Performance in a Transition Economy. Strategic Management Journal, 25, 347364.

Daragahi, G. A. (2017). The Impact of Innovation on Customer Satisfaction: A Study of the Cosmetics Producer in Teheran. International Review, 1(2), 122-132.

DeSarbo, W. S., DiBenedetto, A. C., Song, M., \& Sinha, I. (2005). Revisiting the Miles and Snow Strategic Framework: Uncovering Interrelationships between Strategic Types, Capabilities, Environmental Uncertainty, and Firm Performance. Strategic Management Journal, 26(1), 47-74.

Duysters, G. \& Lokshin, B. (2011). Determinants of Alliance Portfolio Complexity and Its Effect on Innovative Performance of Companies. Journal of Product Innovation Management, 28, 570-585.

Fama, E. F. \& Jensen, M. C. (1983). Agency Problems and Residual Claims. Journal of Law \& Economics, XXVI, 327-349.

Ferdinan (2019). Berita. Retrieved from https://news.detik.com/berita/d-4521928/sof yan-basir-tersangka-korupsi-pltu-riau-1-ini-kata-pengacara (8 September).

Fitriastrini, S. (2017). Praktik Corporate Governance dan Nilai Perusahaan BUMN di Indonesia. Jurnal Riset Manajemen \& Akuntansi, 8(1), 45-98.

Gompers, P. A., Ishii, J. L., \& Metrick, A. (2003). Corporate Governance and Equity Prices. Quarterly Journal of Economics, 118(1), 107-155.

Gonzalez-Fernandez, M., \& Gonzalez-Velasco, C. (2018). Innovation and Corporate Performance in the Spanish Regions. Journal of Policy Modeling, 40(5), 1-44.

Hambrick, D. C. (1983). Some Tests of the Effectiveness and Functional Attributes of Miles and Snow's Strategic Types. Academy of Management Journal, 26(1), 5-25. 
Hambrick, D. C. (2003). On the Straying Power of Defenders, Analyzers, and Prospectors. Academy of Management Executive, 17(4), 115-118.

Hayes, R. H.\& Wheelright, S. C. (1984). Restoring Our Competitive Edge: Competing Through Manufacturing. New York: John Wiley \& Sons, Inc.

Healy, P. M., Bernard, V. L., \& Palepu, K. G. (2003). Business Analysis and Valuation Using Financial Statements: Text and Cases. Third Edition. Ohio: South-Western.

Higgins, D., Omer, T. C., \& Phillips, J. D. (2011). Does a Firm's Business Strategy Influence Its Level of Tax Avoidance? 2011 American Taxation Association Midyear Meeting: JATA Conference, 1-38.

Hitt, M. A., Hoskisson, R. E., \& Kim, H. (1997). International Diversification: Effects on Innovation and Firm Performance in Product Diversified Firms. Academy of Management Journal, 40(4), 767-798.

Yin-Hsi, L. (2012). Managerial Capabilities, Organizational Culture, and Organizational Performance: The Resource-based Perspective in Chinese Lodging Industry. The Journal of International Management Studies, 7(1), 151-157.

Indonesian Corruption Watch (2018). Tren. Retrieved from www.antikorupsi.org: https://antikorupsi.org/id/tren/tren-penindakan-kasus-korupsi-2017 (17 Desember)

Ittner, C. D., Larcker, D. F., \& Rajan, M. V. (1997). The Choice of Performance Measures in Annual Bonus Contracts. The Accounting Review, 72(2), 231-255.

Jensen, M. C. \& Meckling, W. H. (1976). Theory of the Firm: Managerial Behavior, Agency Costs, and Ownership Structure. Journal of Financial Economics, 3(4), 305-360.

Kaplan, R. S. \& Norton, D. P. (1996). Strategic Learning \& the Balanced Scorecard. Strategy \& Leadership, 24(5), 18-24.

Kementerian Badan Usaha Milik Negara Republik Indonesia (2002). Keputusan Menteri Badan Usaha Milik Negara Nomor KEP-117/M-MBU/2002.

Ketchen, D., Thomas, J., \& McDaniel, R. (1996). Process, Content and Context: Synergistic Effects on Organizational Performance. Journal of Management, 231-257.

Kim, K., Hong, E., \& Rho, S. (2013). The Study of Defined Buying Factors Affecting Trust Building and Service Performance in Financial Management Systems. Mathematical and Computer Modelling, 58, 38-48.

Lin, J. Y. (2013). Effects on Diversity of R\&D Sources and Human Capital on Industrial Performance. Technological Forecasting and Social Change, 1-17.

Meier, K. J., O'Toole, L. J. Jr., Boyne, G. A., \& Walker, R. M. (2006). Strategic Management and the Performance of Public Organizations: Testing Venerable Ideas Against Recent Theories. Journal of Public Administration Research and Theory, 17, 357-377.

Miles, R. E., Snow, C. C., Meyer, A. D., \& Coleman, H. J. Jr. (1978). Organizational Strategy, Structure, and Process. The Academy of Management Review, 3(3), 546562.

Naveed, T., Akhtar, I., \& Cheema, K. U. (2013). The Impact of Innovation on Customer Satisfaction and Brand loyalty: A Study of the Students of Faisalabad. International Journal of Management and Organizational Studies, 62-68. 
Nugraheni, P. \& Fauziah, L. (2019). The Impact of Corporate Governance on Customer Satisfaction and Loyalty of Islamic Insurance Company in Indonesia. Journal of Accounting and Investment, 20(2), 115-128.

Oyedijo, A., \& Ro, A. (2012). Organizational Strategy and Firm Performance: A Test of Miles and Snow's Model using 34 Paint Manufacturing SMEs in South-Western Nigeria. Journal of Research in International Business and Management, 2(6), $170-178$.

Pan, Y. \& Zinkhan, G. (2006). Determinants of Retail Patronage: A Meta-Analytical Perspective. Journal of Retailing, 82(3), 229-243.

Parimana, K. \& Wisadha, I. (2015). Pengaruh Privatisasi, Kompensasi Manajemen Eksekutif, dan Ukuran Perusahaan pada Kinerja Perusahaan. E-Jurnal Akuntansi Universitas Udayana, 10(3), 753-762.

Parnell, J. A., \& Wirght, P. (1993). Generic Strategy and Performance: An Empirical Test of Miles and Snow Typology. British Journal of Management, 4, 29-36.

Parnell, J. A. (2010). Strategic Clarity, Business Strategy, and Performance. Journal of Strategy Management, 3, 304-324.

Parnell, J. A., Koseoglu, M. A., Long, Z., \& Spillan, J. E. (2012). Competitive Strategy, Uncertainty, and Performance: An Exploratory Assessment of China and Turkey. Journal of Transnational Management, 17(2), 91-117.

Patel, B. N. \& Cespedes, F. V. (2016). Introduction to Business Strategy. Journal of the American College of Radiology, 13(6), 747-749.

Pearce, J. A. \& Robbins, D. K. (2008). Strategic Transformation as the Last Essential Step in the Process of Business Turnaround. Business Horizons, 51, 121-130.

Peng, M. W., Sun, S. L., Pinkham, B., \& Chen, H. (2009). The Institution-Based View as A Third Leg for A Strategy Tripod. Academy of Management Perspective, 6381.

Porter, M. E. (1980). Competitive Strategy. New York: The Free Press.

Porter, M. E. (1994). Keunggulan Bersaing Menciptakan dan Mempertahankan Kinerja Unggul. Alih Bahasa Tim Penerjemah Binarupa Aksara. Jakarta: Binarupa Aksara.

PT Pindad (Persero) (2017). Pindad Dalam Berita. Retrieved from https://www.pindad. com/pt-pindad-tak-sekadar-memproduksi-senjata (17 Desember).

Purwadi, I. A. (2018a). Berita. Retrieved from https://djakartalloyd.co.id/djakarta-lloydsiap-berperan-melayani-angkutan-curah/ (April 12).

Purwadi, I. A. (2018b). Siaran Pers. Retrieved from https://djakartalloyd.co.id/djakartalloyd-raih-penghargaan-dalam-ajang-bumn-marketeers-awards/ (Mei 3).

Rozie, F. (2019). Peristiwa. Retrieved from https://www.liputan6.com/news/read/394 7938/dalami-korupsi-e-ktp-kpk-periksa-mantan-dirut-pt-len-industri (April 23).

Sekretaris Kementerian Badan Usaha Milik Negara Republik Indonesia (2012). Surat Keputusan Nomor SK-16/S.MBU/2012.

Sami, H., Wang, J., \& Zhou, H. (2011). Corporate Governance and Operating Performance of Chinese Listed Firms. Journal of International Accounting, Auditing and Taxation, 20, 106-114. 
Sarac, M., Ertan, Y., \& Yucel, E. (2014). How Do Business Strategies Predict Firm Performance? An Investigation on Borsa Istanbul Index. The Journal of Accounting and Finance, 121-134.

Siswaji, B., Nuryartono, N., Arifin, B., \& Didu, M. S. (2013). Analisis Pengaruh Institusi terhadap Strategi dan Kinerja Badan Usaha Milik Negara (BUMN). Jurnal Manajemen Teknologi, 12(3), 220-234.

Smith, K. G., Guthrie, J. P., \& Chen, M.J. (1986). Miles and Snow's Typology of Strategy, Organizational Size and Organizational Performance. Academy of Management Proceedings, 45-49.

Smith, K. G., Guthrie, J. P., \& Chen, M.J. (1989). Strategy, Size and Performance. Organization Studies, 10(1), 63-81.

Snow, C. C. \& Hrebiniak, L. G. (1980). Strategy, Distinctive Competence, and Organizational Performance. Administrative Science Quarterly, 25(2), 317-366.

Sukamulja, S. (2004). Good Corporate Governance di Sektor Keuangan: Dampak GCG terhadap Kinerja Perusahaan. Benefit, 8(1), 1-25.

Sun, K. A., \& Kim, D.Y. (2013). Does Customer Satisfaction Increase Firm Performance: An Application. International Journal of Hospitality Management, 35, $68-77$.

Tuli, K. R. \& Bharadwaj, S. G. (2009). Customer Satisfaction and Stock. Journal of Marketing, 73, 184-197.

Sekretariat Negara RI (2003). Undang-Undang Negara Republik Indonesia Nomor 19 Tahun 2003 tentang Badan Usaha Milik Negara.

Volberda, H. W., Weerdt, N. V. D., Verwaal, E., Stienstra, M., \& Verdu, A. J. (2012). Contingency Fit, Institutional Fit, and Firm Performance: A Metafit Approach to Organization-Environment Relationships. Organization Science, 23(4), 10401054. 